\title{
CERITA DONGENG SEBAGAI MEDIA PENDIDIKAN KARAKTER ANAK USIA DINI
}

\author{
Oleh: \\ I Gede Dharman Gunawan ${ }^{1}$, Pranata $^{2}$, Mitro ${ }^{3}$ \\ Pascasarjana UNHI Denpasar ${ }^{1}$, IAHN-TP Palangka Raya2, \\ IAHN-TP Palangka Raya ${ }^{3}$
}

email: dharman.gunawan@gmail.com

\begin{abstract}
Abstrak
Pendidikan karakter kini memang menjadi isu utama pendidikan, selain menjadi bagian dari proses pembentukan akhlak anak bangsa, pendidikan karakter ini pun diharapkan mampu menjadi pondasi utama dalam mensukseskan Indonesia Emas 2025. Penanaman pendidikan karakter dapat diberikan lebih awal kepada anak usia dini melalui media cerita dongeng. Pentingnya cerita dongeng bagi anak usia dini, tidak hanya kegiatan untuk menidurkan anak tetapi juga dapat meningkatkan perkembangan pada otak kanan anak, psikologis, kecerdasan emosional, karakter mulia, serta meningkatkan imajinasi pada anak uasia dini. memberikan cerita dongeng kepada anak merupakan bagian penting dari pengasuhan anak. Selain bermanfaat untuk perkembangan psikologisnya, juga membuat anak merasa disayangi dan diperhatikan oleh orang tua. Sehingga tidak menyebabkan degradasi moral di tengah pesatnya perkembangan teknologi saat ini. Melalui cerita dongeng sebagai media pendidikan karakter bagi anak usia dini, anak akan dapat belajar mengenai dunia, kehidupan, diri sendiri, maupun orang lain.
\end{abstract}

Kata Kunci : Cerita Dongeng, Pendidikan Karakter, Anak Usia Dini 


\section{Pendahuluan}

Masa usia dini anak (rentang 0-6 tahun) adalah masa yang tepat bagi orangtua untuk memberikan pendidikan yang membantu mengembangkan perilaku positif anak. Terlebih, pada masa usia ini merupakan masa keemasan (the golden age), di mana otak mengalami perkembangan yang sangat pesat atau eksplosif. Anak usia dini dapat dikatakan sebagai peniru ulung, di mana anak akan meniru apa yang di lihat, dirasakan, dan di dengar dari lingkungannya. Ini karena, anak usia dini belum mengetahui batasan benar atau salah, baik atau buruk, serta pantas atau tidak pantas. Jadi di masa usia dini, orangtua harus mengoptimalkan pendidikan anak. Salah satunya dengan metode bercerita (mendongeng). Maka, keahlian bercerita merupakan salah satu kemampuan yang harus dikuasai orangtua, dan perlu diaplikasikan secara nyata. Dongeng adalah salah satu pendekatan pembelajaran yang menyenangkan bagi anak. Melalui dongeng dengan cerita yang menarik bagi anak, maka dapat memudahkan anak menyerap informasi. Dongeng yang dapat menarik perhatian anak akan dengan mudah diserap oleh sensor memori untuk kemudian diteruskan ke memori jangka pendek dan akhirnya ke dalam memori jangka panjang (Rosada, 2016: 46).

Cerita dongeng pada umumnya lebih berkesan daripada nasihat murni orangtua. Cerita terekam jauh lebih kuat dalam memori manusia. Cerita/dongeng yang didengar di masa kecil, masih bisa diingat secara utuh selama berpuluh-puluh tahun kemudian. melalui cerita, orangtua dapat menanamkan nilai-nilai moral, dan nilai-nilai karakter. Sehingga, anak nantinya akan tumbuh dan berkembang dengan kepribadian dan akhlak yang terpuji. Efek dari cerita dapat dimanfaatkan orangtua 
sebagai metode mendidik karakter anak. Pada sebuah cerita terdapat amanat yang sangat penting bagi perkembangan pola pikir anak-anak. Begitu pula tokoh dalam cerita dapat menjadi teladan bagi anak-anak.

Sungguh ironis, pada zaman sekarang, media dongeng kian lapuk dan dianggap basi. Dongeng tidak lagi dijadikan andalan dalam mengasah stimulasi anak. Hal ini berakibat kurang pekanya anak terhadap lingkungan sekitar, rasa solidaritas kepada sesama temannya kian rapuh, dan pribadi tolong menolong sangat jarang. Semua berawal ketika para orang tua dan guru anak usia dini tidak bisa mengimbangi arus zaman modern. Mereka lebih asyik membiarkan anak-anaknya. Sebagian besar orang tua maupun pendidik di lembaga pendidikan, seperti pendidikan anak usia dini (PAUD) maupun kanak-kanak mulai cenderung terkesan bosan dan terlihat meragukan keampuhan sebuah dongeng. Meramu sebuah dongeng yang positif merupakan kelebihan tersendiri dari seorang pendidik PAUD. Sayangnya, bila dihadapkan dengan dongeng bagi si anak, mereka masih terkesan ogah-ogahan. Sebagian besar dari mereka, terutama para orang tua di rumah, lebih senang membiarkan anak mereka duduk manis di depan televisi daripada harus menceritakan dongeng kepada anak mereka. Dampaknya adalah jiwa luhur dari isi sebuah dongeng tidak akan tertanamkan ke anak-anak mereka (Sophya, 2018: 184).

Oleh karena itu, sangat penting untuk memberikan cerita dongeng kepada anak yang juga banyak mengajarkan nilai-nilai moral. Hal ini sangat baik bagi perkembangan karakter anak usia dini. Nilai-nilai moral yang terkandung di dalam suatu dongeng diungkapkan pada bagian penutup. Anak-anak akan lebih memahami hubungan sebab akibat dari suatu perbuatan melalui media dongeng. Anak-anak akan 
semakin paham bila segala perbuatan baik akan membuahkan hal yang baik pula, dan segala perbuatan yang tidak baik akan membuahkan sesuatu yang tidak baik pula. Tulisan ini menjelaskan mengenai pentingnya memberikan cerita dongeng sebagai media pendidikan karakter kepada anak usia dini.

\section{Pembahasan}

\subsection{Cerita Dongeng}

Dongeng merupakan cerita pendek yang tidak dianggap benar terjadi. Dongeng diceritakan dengan tujuan untuk menghibur, melukiskan kebenaran, pelajaran (moral) dan sindiran. Pada umumnya cerita dongeng memiliki kalimat pembuka dan penutupnya yang bersifat klise seperti kalimat di awal "Pada suatu waktu hiduplah seorang ...." dan pada kalimat di akhir “.... akhirnya mereka hidup bahagia selamanya". Cerita dongeng bermanfaat bagi anak usia dini, untuk perkembangan secara kognitif (pengetahuan), afektif (perasaan), sosial, dan konatif (penghayatan) anak. Dongeng merupakan suatu cerita yang sifatnya fiksi dan bersifat menyenangkan (menghibur) bagi yang mendengarkannya didalamnya sering didalamnya terkandung unsur-unsur petuah pula (Hanif, 2010).

Dongeng sebagai salah satu dari sastra anak, berfungsi untuk memberikan hiburan, juga sebagai sarana untuk mewariskan nilai-nilai yang diyakini kebenarannya oleh masyarakat pada waktu itu. Dongeng dipandang sebagai sarana untuk mewariskan nilai-nilai, dan untuk masyarakat lama itu dapat dipandang sebagai satu-satunya cara. Sesuai dengan keberadaan misi tersebut, dongeng mengandung ajaran moral. Dongeng sering mengisahkan penderitaan tokoh, namun karena 
kejujuran dan ketahanujiannya tokoh tersebut mendapat imbalan yang menyenangkan. Sebaliknya tokoh jahat pasti mendapat hukuman. (Nurgiyantoro, 2005: 200). Dapat dijelaskan bahwa cerita dongeng pada dasarnya mengandung nilai-nilai yang perlu ditanamkan kepada anak usia dini atau genersi muda. Seperti nilai moral merupakan suatu ajaran berupa petunjuk yang sengaja diberikan tentang berbagai hal yang berhubungan dengan masalah kehidupan. Dalam cerita dongeng, moral atau hikmah yang dipeoleh anak selalu dalam pengertian baik dan mencontoh karakter yang baik.

\subsection{Pemanfaatan Media Sebagai Pendidikan Karakter}

Pendidikan memiliki dua bentuk, yaitu pendidikan yang mengarah pada kognitif dan afektif. Pendidikan kognitif menyasar pada kemampuan intelektual seperti yang dipelajari di sekolah secara formal. Pendidikan afektif mengarah pada pembentukan perilaku yang positif dan lebih dikenal dengan pendidikan karakter. Salah satu isu nasional saat ini adalah upaya peningkatan karakter positif. Banyak kasus menunjukkan produk pendidikan nasional yang terlalu menekankan pendidikan kognitif berdampak pada karakter yang kurang baik. Pandai secara kognitif tetapi karakter yang tidak baik. Seyogyanya karakter anak harus dibentuk sejak usia dini. Namun, cerita anak yang disajikan harus sesuai dengan pertumbuhan dan perkembangan anak, serta sastra anak tersebut wajib mengandung nilai budi pekerti (Juanda, 2018: 12).

Pendidikan karakter akan berhasil bila disertai dengan media pembelajaran yang tepat dan diberikan sejak anak berusia dini. Pendidikan karakter menjadi tanggungjawab semua elemen pendidikan mulai dari dosen, guru, orangtua, dan sistem pendidikan. Kembali ke 
media pembelajaran, terdapat beberapa media yang dapat diterapkan untuk pendidikan karakter. Beberapa beberapa media yang dapat dimanfaatkan sebagai penyampai pendidikan karakter dijelaskan berikut ini.

(1) Cerita bergambar seperti komik seharusnya dapat menjadi media pendidikan karakter. Tips membuat cerita bergambar menjadi media pendidikan karakter dengan membuat cerita semenarik mungkin, mengandung cerita kehidupan sehari-hari,sifatnya pendek, dan isi pendidikan karakter yang menjadi target penyampaian harus ditonjolkan. Pada akhir cerita, berikan satu sesi untuk tanya jawab terkait dengan muatan pendidikan karakter utamanya karakter positif atau negatif yang ada pada cerita.

(2) Mewarnai gambar merupakan salah satu media pendidikan bagi anak usia dini. Anak usia dini sangat menyukai aktivitas mewarnai gambar. Pendidikan karakter dapat disampaikan menggunakan media mewarnai gambar. Sekarang ini telah terdapat buku mewarnai gambar dengan disertai cerita. Sedikit modifikasi adalah membuat buku mewarnai gambar dengan cerita yang didalamnya terdapat muatan pendidikan karakter. Bagian akhir orangtua memberikan penjelasan dari gambar yang telah diwarnai dan memberikan penjelasan karakter positif atau negatif yang terdapat dalam mewarnai gambar yang ada ceritanya.

(3) Cerita dongeng dapat menjadi sarana pendidikan karakter. Dalam dongeng tersebut harus terdapat pendidikan karakter yang akan disampaikan kepada anak-anak seperti pada cerita bergambar ataupun mewarnai gambar. Setelah mendongeng, pendidik harus melakukan dialog dengan anak-anak tentang karakter poisitif atau negatif yang ada 
di dalam dongeng. Pengaruh dongeng yang besar pun terhadap moralitas dan karakter anak-anak sangat mendukung dijadikannya dongeng sebagai cerita pendukung karakter (Soetantyo, 2013: 50).

(4) Media wayang atau boneka merupakan media yang menarik bagi anak-anak karena sifatnya yang kongkret, lucu, dan memungkinkan terjadi dialog antara wayang atau boneka dengan anakanak. Wayang atau boneka yang mewakili karakter positif menjadi model bagi anak-anak.

(5) Musik dan drama juga dapat menjadi media dengan bentuk musik yang ceria dan drama yang menarik bagi anak-anak. Melalui lirik lagu ataupun dialog drama menjadi kekuatan utama penyampai pendidikan karakter. Paling penting adalah harus terjadi dialog antara anak-anak dan penyampai pendidikan karakter.

Beberapa media tersebut merupakan sarana penyampai pendidikan karakter anak usia dini. Pemilihan media disesuaikan dengan kondisi anak usia dini. Diperlukan guru atau orang tua untuk memilih media tersebut.

\subsection{Karakteristik Anak Usia Dini}

Anak usia dini memiliki karakteristik yang khas, baik secara fisik, sosial, moral dan sebagainya. Karakteristik anak usia dini antara lain; a) memiliki rasa ingin tahu yang besar, b) merupakan pribadi yang unik, c) suka berfantasi dan berimajinasi, d) masa paling potensial untuk belajar, e) menunjukkan sikap egosentris, f) memiliki rentang daya konsentrasi yang pendek, g) sebagai bagian dari makhluk sosial (Aisyah, 2010). Usia dini merupakan masa emas, masa ketika anak mengalami pertumbuhan dan perkembangan yang pesat. Pada usia ini 
anak paling peka dan potensial untuk mempelajari sesuatu, rasa ingin tahu anak sangat besar. Hal ini dapat kita lihat dari anak sering bertanya tentang apa yang mereka lihat. Apabila pertanyaan anak belum terjawab, maka mereka akan terus bertanya sampai anak mengetahui maksudnya. Di samping itu, setiap anak memiliki keunikan sendirisendiri yang berasal dari faktor genetik atau bisa juga dari faktor lingkungan. Faktor genetik misalnya dalam hal kecerdasan anak, sedangkan faktor lingkungan bisa dalam hal gaya belajar anak.

Anak usia dini merupakan masa peka dalam berbagai aspek perkembangan yaitu masa awal pengembangan kemampuan fisik motorik, bahasa, sosial emosional, serta kognitif. Perkembangan anak memiliki 4 tingkat perkembangan kognitif yaitu tahapan sensori motorik (0-2 tahun), pra operasional konkrit (2-7 tahun), operasional konkrit (7-11 tahun), dan operasional formal (11 tahun ke atas). Dalam tahap sensori motorik (0-2 tahun), anak mengembangkan kemampuannya untuk mengorganisasikan dan mengkoordinasikan dengan gerakan dan tindakan fisik. Anak lebih banyak menggunakan gerak reflek dan inderanya untuk berinteraksi dengan lingkungannya. Pada perkembangan pra operasional, proses berpikir anak mulai lebih jelas dan menyimpulkan sebuah benda atau kejadian walaupun itu semua berada di luar pandangan, pendengaran, atau jangkauan tangannya. Pada tahap operasional konkrit, anak sudah dapat memecahkan persoalan-persoalan sederhana yang bersifat konkrit dan dapat memahami suatu pernyataan, mengklasifikasikan serta mengurutkan. Pada tahap operasional formal, pikiran anak tidak lagi terbatas pada benda-benda dan kejadian di depan matanya. Pikiran anak terbebas dari kejadian langsung. Dilihat dari perkembangan kognitif, 
anak usia dini berada pada tahap pra operasional. Anak mulai proses berpikir yang lebih jelas dan menyimpulkan sebuah benda atau kejadian walaupun itu semua berada di luar pandangan, pendengaran, atau jangkauan tangannya. Anak mampu mempertimbangkan tentang besar, jumlah, bentuk dan benda-benda melalui pengalaman konkrit. Kemampuan berfikir ini berada saat anak sedang bermain.

Menurut Bredekamp dan Coople (Aisyah, 2010), beberapa prinsip perkembangan anak usia dini yaitu sebagai berikut: Aspekaspek perkembangan anak seperti aspek fisik, sosial, emosional, dan kognitif satu sama lain saling terkait secara erat. Perkembangan anak tersebut terjadi dalam suatu urutan yang berlangsung dengan rentang bervariasi antar anak dan juga antar bidang perkembangan dari masingmasing fungsi. Perkembangan berlangsung ke arah kompleksitas, organisasi, dan internalisasi yang lebih meningkat. Pengalaman pertama anak memiliki pengaruh kumulatif dan tertunda terhadap perkembangan

anak. Perkembangan dan belajar dapat terjadi karena dipengaruhi oleh konteks sosial dan kultural yang merupakan hasil dari interaksi kematangan biologis dan lingkungan, baik lingkungan fisik maupun sosial tempat anak tinggal. Perkembangan mengalami percepatan bila anak memiliki kesempatan untuk mempraktekkan keterampilanketerampilan yang baru diperoleh dan ketika mereka mengalami tantangan. Sarana penting bagi perkembangan sosial, emosional, dan kognitif anak serta merefleksikan perkembangan anak yaitu dengan bermain. Melalui bermain anak memiliki kesempatan dalam pertumbuhan dan perkembangannya sehingga anak disebut dengan 
pembelajar aktif. Anak akan berkembang dan belajar dengan baik apabila berada dalam suatu konteks komunitas yang aman (fisik dan psikologi), menghargai, memenuhi kebutuhan-kebutuhan fisiknya, dan aman secara psikologis. Anak menunjukkan cara belajar yang berbeda untuk mengetahui dan belajar tentang suatu hal yang kemudian mempresentasikan apa yang mereka tahu dengan cara mereka sendiri. Dari berbagai uraian, dapat disimpulkan bahwa prinsip-prinsip anak usia dini adalah anak merupakan pembelajar aktif. Perkembangan dan belajar anak merupakan interaksi anak dengan lingkungan antara lain melalui bermain dan cerita dongeng.

\subsection{Pentingnya Cerita Dongeng Sebagai Media Pendidikan Karakter Anak Usia Dini}

Pada era globalisasi ini, pendidikan karakter perlu menjadi perhatian. Hal ini dalam rangka mempersiapkan generasi yang berkualitas dan menjunjung nilai-nilai luhur bangsa Indonesia. Pendidikan karakter dilakukan untuk membentuk pribadi generasi penerus bangsa yang sesuai dengan identitas bangsanya. Tidak hanya mengenal baik dan buruk. Tapi bagaimana memahaminya, menghayatinya dan mengamalkannya. Adapun 18 nilai-nilai pendidikan karakter yaitu religius, jujur, toleransi, disiplin, kerja keras, kreatif, mandiri, demokratis, rasa ingin tahu, semangat kebangsaan, cinta tanah air, menghargai prestasi, bersahabat/komunikatif. Selain itu, juga nilai cinta damai, gemar membaca, peduli lingkungan, peduli sosial, dan tanggungjawab.

Pendidikan karakter tentunya bukanlah ilmu praktis yang dengan mudah bisa ditanamkan pada diri seseorang begitu saja. 
Menumbuhkan karakter seseorang tentunya membutuhkan sebuah proses panjang. Proses terbaik dimulainya pendidikan karakter adalah sejak usia dini. Pendidikan karakter sejak usia dini, diyakini memiliki peranan yang sangat penting dalam memberikan kemampuan dan sikap dasar bagi seorang anak sejak berada di usia emasnya. Maka, menjadi strategis bila Lembaga Pendidikan Anak Usia Dini (PAUD) menggiatkan pendidikan karakter dalam proses pembelajarannya. Di lingkungan keluarga, peran orangtua juga sangat penting untuk pendidikan karakter kepada anak. Dewasa ini sangat diperlukan pendidikan pada anak usia dini untuk pembentukan karakter anak, karena Indonesia sedang mengalami krisis karakter dalam diri anak bangsa. Tentang fenomena degradasi moral yang melanda anak-anak sering dijumpai saat ini. Zaman sekarang anak tumbuh dewasa tanpa adanya pembekalan karakter, untuk itu sebuah pendidikan karakter perlu diberikan kepada anak, mengingat merekalah kelak harapan dalam membangun bangsa (Fitroh, 2015: 96).

Pendidikan karaker juga dapat ditanamkan di luar sekolah, misalnya di lingkungan keluarga. Cara yang dapat dilakukan adalah (1) orangtua atau saudara membacakan dongeng sebelum tidur atau di waktu luang; (2) di rumah disediakan bacaaan-bacaan dongeng sehingga bisa menarik minat anak untuk membaca; (3) orangtua mengajukan pertanyaan kepada anak untuk melihat pemahaman dan ingatan anak tentang isi dongeng; dan (4) orangtua mengajak anak ke toko buku dan memberikan kesempatan pada anak untuk membeli buku yang disukainya, termasuk dongeng (Habsari, 2017: 27).

Ada beberapa karakter anak yang dapat ditumbuhkan dengan cara mendongeng, antara lain rasa ingin tahu, gemar membaca, kepedulian 
terhadap lingkungan dan sosial, cinta tanah air. Hal ini didapat dari nilai-nilai luhur dan nasehat yang terkandung dalam cerita yang disampaikan. Pemilihan tema cerita untuk anak dapat disesuaikan dengan usia anak. Selain itu pendidikan karakter anak yang dapat ditumbuhkan dengan cara mendongeng, antara lain pertama, menanamkan etika dan nilai-nilai kehidupun, misalnya kejujuran, rendah hati, rasa empati, juga sikap tolong menolong. Saat mendongeng orang tua harus pandai memilih isi cerita yang hendak diberikan kepada anak. Banyak ahli menyarankan untuk tidak mermberikan cerita dengan tokoh yang berwatak jahat. Pemilihan tema cerita untuk anak dapat disesuaikan dengan usia anak. Kedua, kepedulian terhadap lingkungan dan sosial, cinta tanah air. Hal ini didapat dari nilai-nilai luhur dan nasehat yang terkandung dalam cerita yang disampaikan. Seperti cerita rakyat, fabel, hingga yang bersifat tematik seperti transportasi, kebersihan, kesehatan dan sebagainya. Diharapkan dapat membangkitkan kembali budaya mendongeng, menumbuhkan minat anak untuk membaca, membantu orangtua untuk mendongeng kepada anak-anaknya, sebagai sarana edukasi, serta meningkatkan kemampuan anak dalam berpikir dan bernalar (Aprilliani, 2015: 45).

Perlu diperhatikan juga, agar dongeng menarik dan pesan cerita dapat disampaikan dengan baik, dapat dilakukan dengan berbagai cara mendongeng. Cara yang dapat dilakukan antara lain dengan membacakan buku dongeng bergambar, menggunakan peralatan seperti boneka tangan, dengan gaya bahasa dan gaya tubuh, atau dengan cara menggambar langsung. Sangat disayangkan memang, bila saat ini jarang sekali guru atau orang tua yang mau menggunakan dongeng 
sebagai cara untuk menyampaikan pesan atau amanat dalam sebuah pembelajaran. Bahkan, para orang tua pun sudah enggan memakai dongeng untuk meninabobokkan anak tercintanya sesaat sebelum tidur. Mendongeng atau story telling adalah kegiatan paling positif bagi perkembangan anak dalam berbagai aspek. Banyak manfaat yang dapat diambil dari kegiatan tersebut, diantaranya menumbuhkan minat baca anak, dan menanamkan berbagai pesan moral yang disampaikan melalui sebuah cerita atau dongeng (Syukria, 2018: 91).

Padahal, banyak perbedaan pada tumbuh kembang anak yang sering dibacakan dongeng dan anak yang jarang mendengar dongeng. Anak yang sering mendengar dongeng akan memiliki kosakata dan bahasa yang jauh lebih beragam. Kemampuan komunikasi mereka jauh lebih baik. Salah satu tugas pokok pendidik adalah mencerdaskan kehidupan bangsa, dengan menanam dan menumbuhkan pewarisan nilai-nilai hidup sebagai suatu bangsa yang mempunyai cita-cita luhur berdasarkan Pancasila. Terkait hal itu, berbagai cara harus dilakukan guru dan orang tua agar tujuan pendidikan yang ingin dicapai dan karakter bangsa yang diharapkan, bisa masuk dan tertanam dalam mental anak didik. Termasuk menggunakan media cerita dongeng untuk menanamkan karakter mulia kepada anak usia dini.

\section{Penutup}

Pendidikan karakter bukanlah ilmu praktis yang dengan mudah bisa ditanamkan pada diri seseorang begitu saja. Pendidikan karakter membutuhkan sebuah proses panjang. Proses terbaik dimulainya pendidikan karakter adalah sejak anak usia dini. Karena pada usia tersebut merupakan masa-masa keemasan anak, sehingga diyakini 
nilai-nilai karakter akan terpatri kuat di dalam hati dan pikiran anak yang jernih. Salah satu cara menanamkan karakter positif yang menyenangkan anak adalah melalui cerita dongeng. Di mulai dengan ruang lingkup terkecil dari keluarga, bagi anak-anak mendengarkan dongeng atau cerita yang diceritakan oleh orang tuanya dapat mengasah fantasi dan imajinasi anak. Selain sebagai sarana untuk mendekatkan hubungan antara orang tua dan anak, orang tua juga dapat menyampaikan pesan-pesan moral kepada anak. Sehingga anak dapat mengetahui mana perbuatan baik dan buruk, dan menjadikan pondasi karakter bagi anak usia dini.

\section{Referensi}

Aisyah, Siti. (2010). Perkembangan dan Konsep Dasar Pengembangan Anak Usia Dini. Jakarta : Universitas Terbuka.

Aprillini, A., Isnanto, R. R., \& Kridalukmana, R. (2015). Aplikasi Pembaca Dongeng Anak Indonesia Berbasis Android. Jurnal Teknologi dan Sistem Komputer, 3(1), 44-50.

Fitroh, S. F., \& Sari, E. D. N. (2015). Dongeng Sebagai Media Penanaman Karakter Pada Anak Usia Dini. Jurnal PGPAUD Trunojoyo: Jurnal Pendidikan dan Pembelajaran Anak Usia Dini, 2(2), 95-105.

Habsari, Z. (2017). Dongeng Sebagai Pembentuk Karakter Anak. Bibliotika: Jurnal Kajian Perpustakaan dan Informasi, 1(1), 21-29.

Hanif, M. (2010). Dongeng/Cerita Dalam Perspektif Pendidikan. Jurnal Pendidikan, 16(1).

Juanda, J. (2018). Revitalisasi Nilai Dalam Dongeng Sebagai Wahana Pembentukan Karakter Anak Usia Dini. Jurnal Pustaka Budaya, 5(2), 11-18. 
Rosada, U. D. (2016). Memperkuat Karakter Anak Melalui Dongeng Berbasis Media Visual. Jurnal CARE (Children Advisory Research and Education), 4(1), 42-49.

Soetantyo, S. P. (2013). Peranan Dongeng dalam Pembentukan Karakter Siswa Sekolah Dasar. Jurnal Pendidikan, 14(1), 4451.

Sophya, I. V. (2018). Membangun Kepribadian Anak Dengan Dongeng. Thufula: Jurnal Inovasi Pendidikan Guru Raudhatul Athfal, 2(1), 183-199.

Syukria, S., \& Siregar, N. S. S. (2018). Buku Cerita Si Kancil dan Perilaku Meniru Siswa Taman Kanak-kanak. Gondang: Jurnal Seni dan Budaya, 2(2), 90-102. 